\title{
33. TRACE FOSSILS AND ICHNOFABRIC IN LEG 119 CORES ${ }^{1}$
}

\author{
M. L. Droser ${ }^{2}$ and D. J. Bottjer ${ }^{3}$
}

\begin{abstract}
Trace fossils and ichnofabric were examined from cores of Late Cretaceous to Quaternary age recovered from the Kerguelen Plateau, Indian Ocean. Nearly all of the strata are completely bioturbated, with ichnofabric index 6 most commonly recorded. Preserved discrete trace fossils include Chondrites, Planolites, Zoophycos, and Thalassinoides. A continuous Cretaceous/Tertiary boundary section preserved at ODP Site 738 occurs within a 15 -cm-thick interval of laminated sediments. The lack of bioturbation indicates the disappearance of bioturbating organisms from the seafloor, possibly as a result of the same factors that caused the mass extinction or changes in other environmental conditions-most probably, bottom-water oxygen concentrations.
\end{abstract}

\section{INTRODUCTION}

In core studies trace fossils provide important paleoenvironmental information and are commonly also the primary evidence for the composition and behavior of the macrofauna. Much of the record of bioturbation, however, consists of what has commonly been termed "mottled bedding." Ichnofabric is sedimentary rock fabric resulting from biogenic reworking (Ekdale et al., 1984). Thus, ichnofabric records the total extent of preserved bioturbation, including discrete trace fossils as well as mottled bedding. Studies of ichnofabric can be used to document the amount of bioturbation and thus the amount of mixing. The presence of extensive, well-preserved bioturbation structures in cores from Ocean Drilling Program (ODP) Leg 119 has provided the opportunity to develop the use of modern approaches for the measurement of ichnofabric in Deep Sea Drilling Project (DSDP) and ODP cores.

Ichnofabric and discrete trace fossils were studied from cores recovered from Leg 119 Sites 737 and 738 on the Kerguelen Plateau in the Indian Ocean (Fig. 1). Because the goals of this study were directed in part toward development of methodology, no attempt was made to study every core from Leg 119. Specifically, cores from Holes $737 \mathrm{~B}$ and $738 \mathrm{C}$ were examined because these holes contain a representative section of Upper Cretaceous and Tertiary sediments, much of which is lithified, and include a variety of lithofacies. Lithofacies present include (1) nannofossil ooze, (2) diatom ooze, (3) calcareous claystone, (4) calcareous chalk, (5) nannofossil chalk, (6) limestone, and (7) calcareous sandy siltstone. Combinations of these lithofacies are common within cores. Trace fossils and ichnofabric are best preserved in lithified sediments, which in these cores include chalk, limestone, and sandy siltstone. The oozes are generally soft and soupy and although bioturbation can be recognized (see also Barron, Larsen, et al., 1989), primary sedimentary structures (physical and/or biological) are not well preserved. This is due in part to the drilling process. Trace fossils and ichnofabric data were examined from those facies and cores where preservation was best. Although most of the data were recorded from consecutive sections, no attempt was made to completely

\footnotetext{
${ }^{1}$ Barron, J., Larsen, B., et al., 1991. Proc. ODP, Sci. Results, 119: College Station, TX (Ocean Drilling Program).

2 Department of Earth Sciences, University of California, Riverside, CA 92521, U.S.A.

3 Department of Geological Sciences, University of Southern California, Los Angeles, CA 90089 , U.S.A.
}

survey ichnofabric and trace fossils because particular lithofacies are not conducive to ichnological analysis.

Rocks and sediments recovered from Sites 737 and 738 reflect deposition in shelf and deep-sea settings (Barron, Larsen, et al,. 1989). In the absence of anoxic and high-turbulence events, bioturbation in these settings tends to completely disrupt original primary physical sedimentary structures. Berger and Heath (1968) modeled mixing by benthic organisms that can easily be applied to shelf and deep-sea carbonate sediments (see also Ekdale, 1980; Ekdale et al., 1984). Three zones are recognized. The mixed layer, $5-8 \mathrm{~cm}$ below the sediment/water interface, is a zone of homogenization of sediments. In the transition zone, $20-35 \mathrm{~cm}$ below the surface, mixing still occurs but at lower rates. In the underlying historical layer no new burrows are emplaced. Burrows constructed in the transition zone include those that are eventually preserved in the historical layer. Thus, the preserved burrows comprising the shelf and deep-sea ichnofacies are those that for the most part were produced deep in the sediment below the mixed layer. Types of trace fossils that are commonly preserved in these sediments include Chondrites, Planolites, Zoophycos, and Thalassinoides (see also Ekdale, 1977, 1980).

In this paper we examine the distribution of discrete trace fossils as well as apply a new method for quantitatively evaluating ichnofabric.

\section{METHODS}

In previous core and field descriptions of the extent of bioturbation, most workers have employed a descriptive approach. Thus, the literature contains many cases where the extent of bioturbation is reported as "weakly bioturbated," "moderately bioturbated," and "commonly bioturbated." The problem with this approach is that there is no basis for comparison of the extent of bioturbation between the same facies, or between beds of different facies. Proposed classification schemes of ichnofabric based on the amount of disturbed original sedimentary fabric include that previously used by DSDP/ODP sedimentologists. However, none of these include a standardized semiquantitative field and laboratory methodology for measuring ichnofabric.

Droser and Bottjer (1986) established a classification scheme for ichnofabric based on the amount of original physical sedimentary structures disrupted by biogenic reworking, from no bioturbation to complete homogenization (ichnofabric indices (ii) 1 to 6 , respectively). These indices can be represented by schematic diagrams, or "flash cards," such as those in Droser and Bottjer (1986) for thin-bedded shelf carbonates or those shown in Figure 2, which we have developed for cores. The flash 


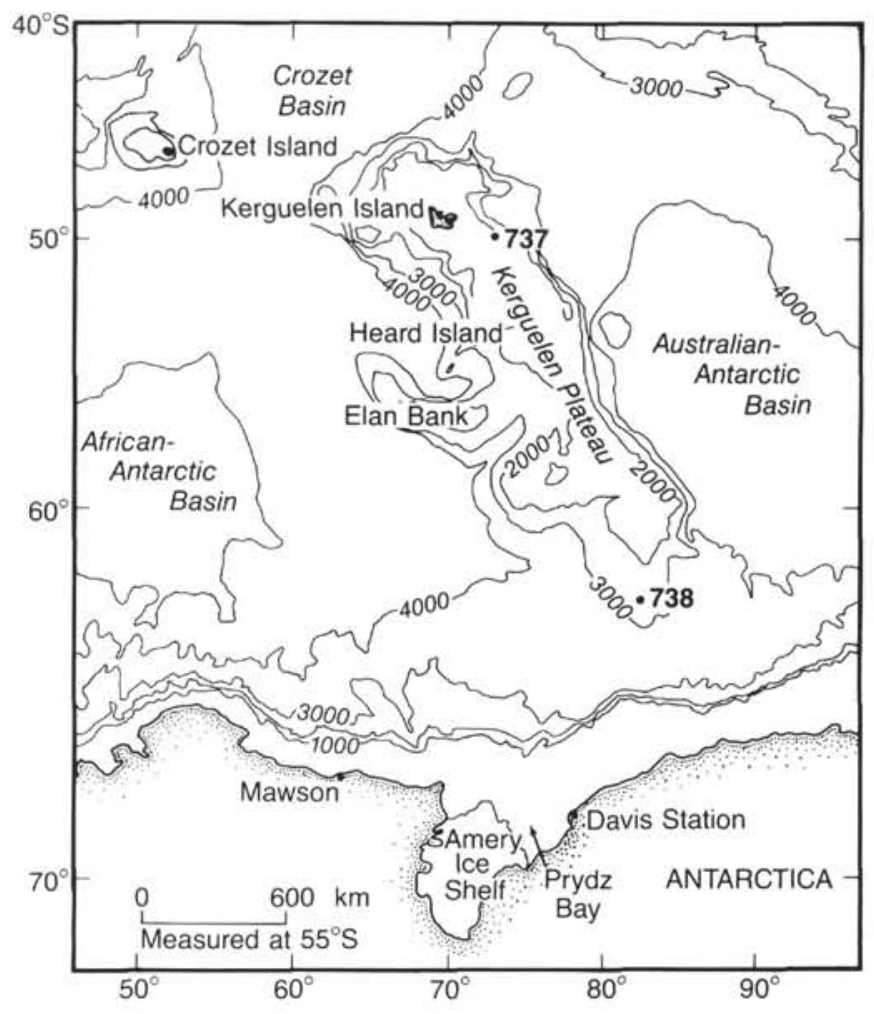

Figure 1. The Kerguelen Plateau and Prydz Bay with Leg 119 Sites 737 and 738 (after Barron, Larsen, et al., 1989).

cards can be used to evaluate the extent of bioturbation in cores. This methodology is analogous to use of the charts found in Terry and Chilingar (1955) for estimating percent composition of rocks and sediments. Sections are logged for ichnofabric in a manner similar to the continuous logging of strata for properties such as rock color or lithology (e.g., Fig. 3; Droser and Bottjer, 1988; Bjerstedt and Erickson, 1989).

In that sediments in shelf and bathyal settings tend to be thoroughly homogenized, ichnofabric index 6 is recorded for most of the strata deposited in these environments. To describe and account for the discrete trace fossils emplaced last on a background of completely homogenized sediment (ii6), a second series of flash cards was developed (Fig. 2). The definitions of ii2, ii3, and ii4 are superimposed on a background of ii6. For example, several discrete burrows preserved on completely homogenized sediment might be classified as ii3/6 (Pl. 1, Fig. 1). This is equivalent to the DSDP/ODP classification of "moderately bioturbated" in relatively homogeneous oozes. This second-series method is simply a descriptive method with no real biological meaning except for the presence of the specific makers of the discrete trace fossils.

\section{TRACE FOSSIL FACIES AND ICHNOFABRIC}

Trace fossils recorded in cores from Holes 737B and 738C include Chondrites, Planolites, Zoophycos, Skolithos, Helminthoida, and Thalassinoides. Trace fossil descriptions can be found in Häntzschel (1975) and Ekdale (1977, 1978). Chondrites and Planolites are ubiquitous. Chondrites commonly occurs in clusters and in burrow fills (Pl. 1, Fig. 2) but is not restricted to either. Zoophycos occurs in nearly all strata but is rare in the upper Oligocene and absent in the middle Miocene.
Skolithos is uncommon but occurs throughout. Helminthoida is relatively rare.

Thalassinoides is a three-dimensional boxwork structure constructed in modern environments by callianassid shrimp (Pl. 1, Fig. 3). It is uncommon in previously described DSDP and ODP cores. In part, the absence of Thalassinoides in DSDP cores is due to the rarity of Thalassinoides in deep-sea sediments. However, the geometry of Thalassinoides works against easy recognition of Thalassinoides in a core exposure. Unlike Zoophycos and Chondrites, which have characteristic morphologies in cores, Thalassinoides may appear similar to a Planolites burrow or a Skolithos burrow or may simply appear as an "indistinct large burrow" or "complex burrow." Recognizable Thalassinoides occur in the oldest and youngest strata studied.

The cores recovered are nearly totally bioturbated throughout. Laminated sediments are rare in cores recovered from both sites. Primary laminations are uncommon, but significantly, they do occur just below and above the Cretaceous/Tertiary boundary, as discussed in the following section. Diagenetic laminations, however, are relatively common and can be confused with primary physical structures. Two types of facies-dependent diagenetic laminations occur throughout. Laminations possibly due to diagenetic redox cycles occur throughout the limestone and chalk (Pl. 1, Fig. 4). These laminations are grouped in dark and light green color alternations on a scale of millimeters to centimeters in thickness. They crosscut burrows, thereby confirming their secondary origin. A second type of lamination also appears to be diagenetic in origin. Chalk facies appear to have laminated or "crinkly" beds that may look primary in origin. Although these were not studied in detail, they appear to be similar to those described by Ekdale and Bromley (1988) from 


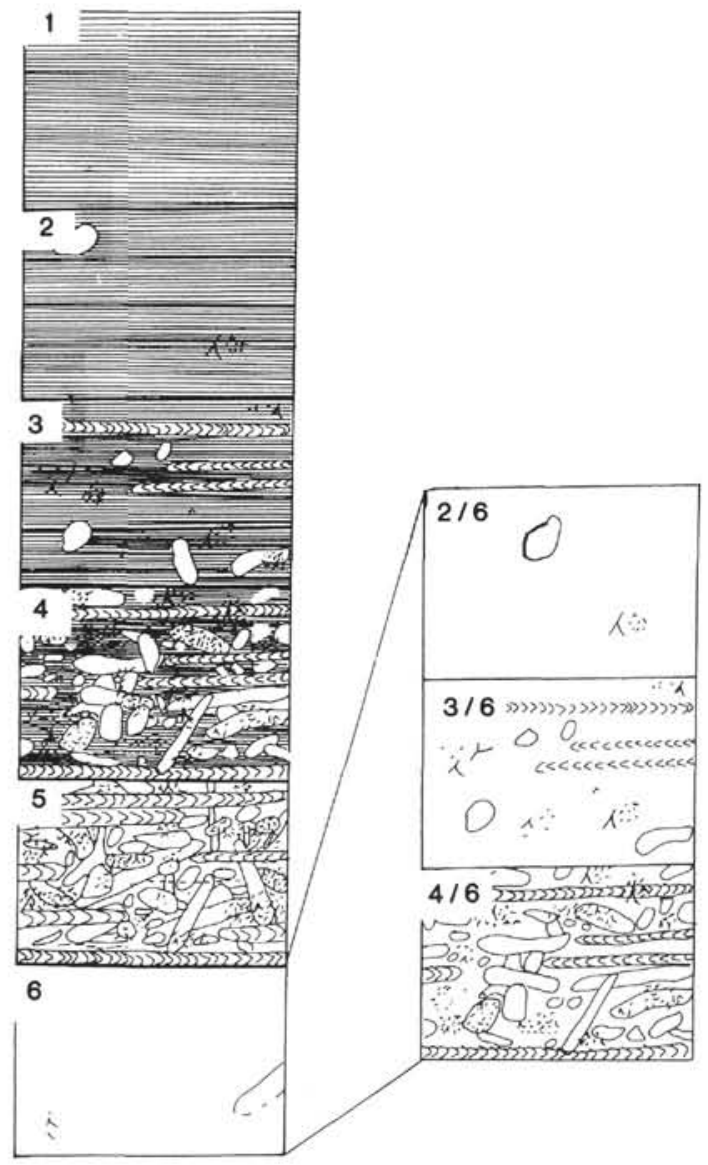

Figure 2. Schematic diagrams for ichnofabric indices 1 through 6 and $2 / 6$ through $4 / 6$. Ichnofabric indices are defined (Droser and Bottjer, 1986) as follows: 1. No bioturbation recorded; all original sedimentary structures. 2. Discrete, isolated trace fossils; up to $10 \%$ of original bedding disturbed. 3. Approximately $10 \%$ to $40 \%$ of original bedding disturbed. Burrows are generally isolated, but locally overlap. 4 . Last vestiges of bedding discernible; approximately $40 \%-60 \%$ disturbed. Burrows overlap and are not always well defined. 5. Bedding is completely disturbed, but burrows are still discrete in places and the fabric is not mixed. 6. Sediment is nearly or totally homogenized. Discrete trace fossils are no longer visible. 2/6. Discrete isolated trace fossils on a background of ii6. 3/6. Discrete trace fossils occur over $10 \%-40 \%$ of the view with a background of ii6. 4/6. Overlapping but still visible discrete trace fossils on a background of ii6.

chalks in Denmark, which they interpreted to be most likely a pressure-solution feature. Several types of chalk-solution structures have been described from DSDP cores (Hill, 1987).

\section{Site 738}

Cores examined from Site 738 (on the southern tip of the Kerguelen Plateau; Fig. 1) include strata of early Turonian through Quaternary age. Trace fossils and ichnofabric were evaluated from calcareous chalk (Cores 119-738C-10R and 119-738C-19R through 119-738C-24R) and limestones (Cores 119-738C-25R through 119-738C-31R) corresponding to Units V and VI of Barron, Larsen, et al. (1989). These strata are of early Turonian to early Eocene age. The calcareous chalk is a white to light greenish gray chalk with chert nodules and fragments and minor foraminifers and nannofossils. The limestone is light gray to olive gray and contains minor clay, chert nodules and fragments, and Inoceramus fragments. These cores are also of significance

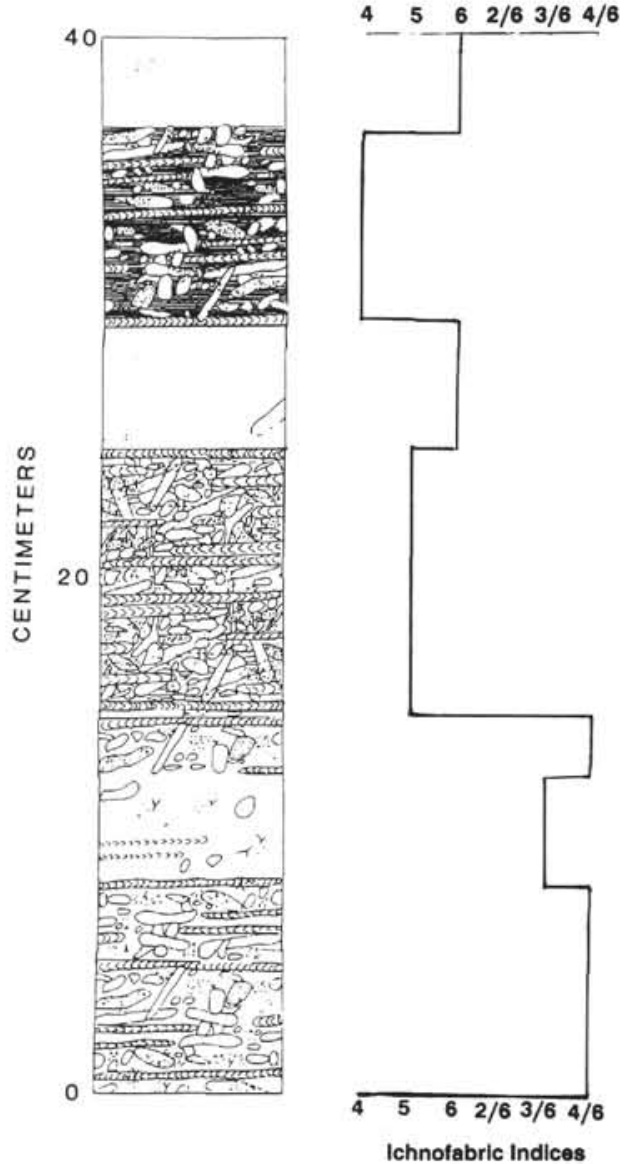

Figure 3. Schematic diagram of a 6-7-cm-wide core section logged for ichnofabric indices.

because they contain a preserved continuous section across the Cretaceous/Tertiary boundary.

Chondrites and Planolites are present in nearly all of the examined sections. Zoophycos similarly occurs throughout, but not in all sections (Table 1). Thalassinoides is preserved only in the Cretaceous limestone. Skolithos is present only rarely throughout the cores. Depth of bioturbation recorded from Skolithos burrows ranges up to $11 \mathrm{~cm}$. Overall, nearly all strata are thoroughly bioturbated and recorded as ii6 (i.e., ii6, ii $2 / 6$, ii3/6, and ii4/6). Rare ii1 with associated ii2, ii3, and ii4 was also recorded.

\section{Cretaceous/Tertiary Boundary}

The Cretaceous/Tertiary boundary is preserved in Section 119-738C-20R-5 within a 15-cm-thick interval of iil (Pl. 1, Fig. 5). The lack of bioturbation in this interval is important for two reasons: (1) as noted by others, it provides a setting where highresolution studies of microfossils can determine the mass extinction rebound and (2) the lack of bioturbation, however, indicates the disappearance of bioturbating organisms from the seafloor, which is due to the same factors that caused the mass extinction or some other environmental changes-most probably, bottom-water oxygen concentrations. Intervals deposited under oxygen-deficient conditions associated with Cretaceous/Tertiary boundary sections have been recognized elsewhere (Ekdale and Bromley, 1984b). Within the laminated sequence is a mixed Cretaceous and Tertiary fauna (Barron, Larsen, et al., 1989). There is no major change in the nature of bioturbation across the boundary. Immediately adjacent to the laminated strata both 
Table 1. Distribution of trace fossils and ichofabric indices.

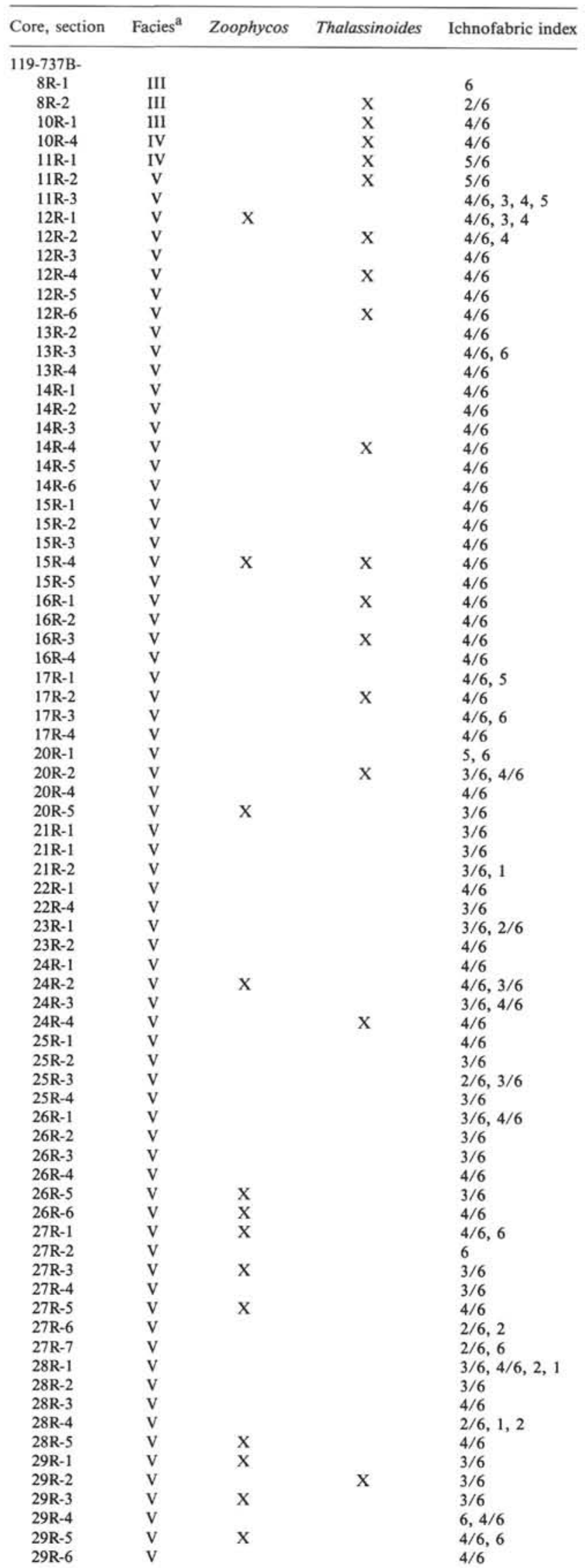

Table 1 (continued).

\begin{tabular}{|c|c|c|c|c|}
\hline Core, section & Facies $^{\mathrm{a}}$ & Zoophycos & Thalassinoides & Ichnofabric index \\
\hline \multicolumn{5}{|c|}{ 119-737B-(Cont.) } \\
\hline 29R-7 & $\mathrm{v}$ & $\mathrm{x}$ & & $4 / 6,3 / 6,2 / 6$ \\
\hline $30 \mathrm{R}-2$ & $\mathrm{v}$ & $\mathrm{x}$ & & $3 / 6,2 / 6$ \\
\hline $30 \mathrm{R}-4$ & $v$ & & & $6,3 / 6,2 / 6$ \\
\hline $30 \mathrm{R}-5$ & $\mathrm{v}$ & & & $3 / 6,4 / 6,1$ \\
\hline $31 \mathrm{R}-1$ & $\mathrm{v}$ & & & $2 / 6,4 / 6,1$ \\
\hline $31 \mathrm{R}-2$ & $\mathrm{v}$ & $\mathrm{x}$ & & $4 / 6,2,4$ \\
\hline $31 \mathrm{R}-3$ & $\mathrm{v}$ & $\mathrm{x}$ & & $4 / 6,1,3$ \\
\hline $31 \mathrm{R}-4$ & $\mathrm{v}$ & $\mathrm{x}$ & & $4 / 6,6,3 / 6$ \\
\hline $31 \mathrm{R}-5$ & $\mathrm{v}$ & $\mathrm{X}$ & & $6,4 / 6,3 / 6$ \\
\hline $31 \mathrm{R}-6$ & $\mathrm{v}$ & $\mathrm{x}$ & & $4 / 6$ \\
\hline $31 \mathrm{R}-7$ & $\mathrm{v}$ & & & $6,2 / 6$ \\
\hline $33 \mathrm{R}-1$ & $\mathrm{v}$ & & & 6 \\
\hline $33 \mathrm{R}-2$ & $\mathrm{v}$ & $\mathrm{x}$ & & $3 / 6,6$ \\
\hline $33 R-3$ & $\mathrm{v}$ & & & $3 / 6$ \\
\hline $34 \mathrm{R}-1$ & $\mathrm{v}$ & & & $3 / 6$ \\
\hline $34 \mathrm{R}-2$ & $\mathrm{v}$ & $\mathrm{x}$ & & $3 / 6$ \\
\hline $34 \mathrm{R}-5$ & $\mathrm{v}$ & & & $3 / 6$ \\
\hline $35 \mathrm{R}-1$ & $\mathrm{v}$ & $\mathrm{x}$ & & $2 / 6$ \\
\hline $35 \mathrm{R}-2$ & $\mathrm{v}$ & $\mathrm{x}$ & & $3 / 6$ \\
\hline $35 \mathrm{R}-5$ & v & $\mathrm{x}$ & & $3 / 6$ \\
\hline $36 \mathrm{R}-2$ & v & & & $2 / 6,3 / 6$ \\
\hline $36 \mathrm{R}-3$ & $\mathrm{v}$ & $\mathrm{X}$ & & $3 / 6$ \\
\hline $37 \mathrm{R}-1$ & $\mathrm{v}$ & $\mathrm{X}$ & & $3 / 6$ \\
\hline $37 \mathrm{R}-2$ & $\mathrm{v}$ & $\mathrm{X}$ & & $3 / 6$ \\
\hline $37 \mathrm{R}-3$ & $\mathrm{v}$ & $\mathrm{X}$ & & $3 / 6$ \\
\hline $37 \mathrm{R}-4$ & $\mathrm{v}$ & $\mathrm{x}$ & & $4 / 6$ \\
\hline $37 \mathrm{R}-5$ & $\mathrm{v}$ & $\mathrm{x}$ & & $2 / 6$ \\
\hline $37 \mathrm{R}-6$ & $\mathrm{v}$ & & & $2 / 6$ \\
\hline $38 \mathrm{R}-1$ & $\mathrm{v}$ & $\mathrm{x}$ & & $3 / 6,6,4 / 6$ \\
\hline $38 \mathrm{R}-2$ & $\mathrm{v}$ & $\mathrm{x}$ & & $4 / 6$ \\
\hline $38 \mathrm{R}-3$ & $\mathrm{v}$ & & & $3 / 6$ \\
\hline $38 \mathrm{R}-4$ & $\mathrm{v}$ & & & $6,3 / 6$ \\
\hline $38 \mathrm{R}-5$ & v & $\mathrm{X}$ & & $6,3 / 6$ \\
\hline $38 \mathrm{R}-6$ & $\mathrm{v}$ & $\mathrm{x}$ & & $3 / 6$ \\
\hline $39 \mathrm{R}-1$ & v & $\mathrm{x}$ & & $3 / 6$ \\
\hline $39 \mathrm{R}-2$ & v & $\mathrm{X}$ & & $3 / 6$ \\
\hline $39 \mathrm{R}-3$ & $\mathrm{v}$ & $\mathrm{x}$ & & $3 / 6$ \\
\hline $39 R-4$ & v & $\mathrm{x}$ & & $3 / 6$ \\
\hline $39 \mathrm{R}-5$ & $\mathrm{v}$ & & & $4 / 6$ \\
\hline $39 \mathrm{R}-6$ & $\mathrm{v}$ & $\mathrm{X}$ & & $4 / 6$ \\
\hline $40 \mathrm{R}-1$ & $\mathrm{v}$ & $\mathrm{x}$ & & $2 / 6$ \\
\hline $42 \mathrm{R}-1$ & $\mathrm{v}$ & $\mathrm{x}$ & & $3 / 6$ \\
\hline $42 R-2$ & $\mathrm{v}$ & $\mathrm{x}$ & & 6 \\
\hline $42 \mathrm{R}-3$ & v & $x$ & & $3 / 6$ \\
\hline $42 R-4$ & v & $\mathrm{x}$ & & $3 / 6$ \\
\hline $42 R-5$ & v & $\mathrm{X}$ & & $3 / 6$ \\
\hline $42 \mathrm{R}-6$ & V & $\mathrm{x}$ & & $3 / 6$ \\
\hline
\end{tabular}

$119-738 \mathrm{C}$ -

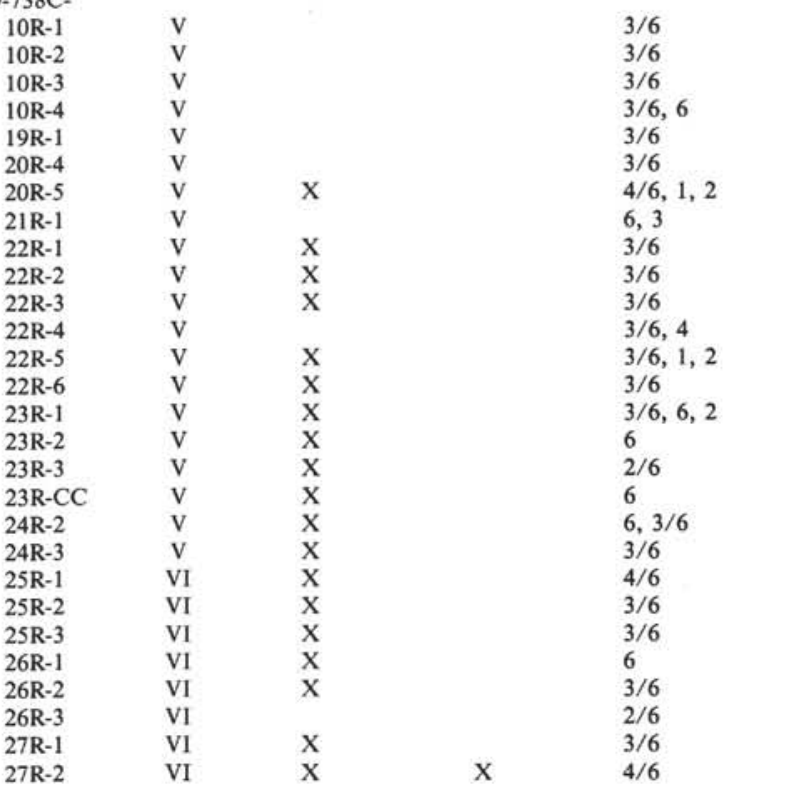


Table 1 (continued).

\begin{tabular}{|c|c|c|c|c|}
\hline Core, section & Facies $^{\mathrm{a}}$ & Zoophycos & Thalassinoides & Ichnofabric index \\
\hline \multicolumn{5}{|c|}{ 119-738C-(Cont.) } \\
\hline $27 \mathrm{R}-3$ & VI & & & $3 / 6$ \\
\hline $27 R-4$ & VI & & & $3 / 6$ \\
\hline $27 R-5$ & VI & & & $4 / 6$ \\
\hline 28R-1 & VI & & & $6,4,1,5$ \\
\hline $28 \mathrm{R}-2$ & VI & & & $2 / 6$ \\
\hline $28 \mathrm{R}-3$ & V1 & & & $3 / 6,2 / 6$ \\
\hline $28 \mathrm{R}-4$ & VI & & & $4 / 6,2 / 6$ \\
\hline $29 \mathrm{R}-1$ & VI & $\mathrm{x}$ & & $6,4 / 6$ \\
\hline $29 \mathrm{R}-2$ & VI & & & $4 / 6,6,3 / 6$ \\
\hline $29 \mathrm{R}-3$ & VI & & & $3 / 6$ \\
\hline $30 \mathrm{R}-1$ & VI & $\mathrm{x}$ & & $3 / 6$ \\
\hline 30R-2 & VI & $\mathrm{X}$ & & $3 / 6$ \\
\hline $30 \mathrm{R}-3$ & VI & & & $2 / 6$ \\
\hline 31R-1 & VI & & & $3 / 6$ \\
\hline $31 R-2$ & VI & & & $2 / 6$ \\
\hline $31 R-3$ & VI & & & 6 \\
\hline $31 R-4$ & $\mathrm{v}$ & $\mathrm{x}$ & & $4 / 6,6,3 / 6$ \\
\hline $31 \mathrm{R}-5$ & V & $\mathrm{X}$ & & $6,4 / 6,3 / 6$ \\
\hline $31 \mathrm{R}-6$ & V & $\mathrm{x}$ & & $4 / 6$ \\
\hline $31 \mathrm{R}-7$ & V & & & $6,2 / 6$ \\
\hline $33 \mathrm{R}-1$ & v & & & 6 \\
\hline $33 \mathrm{R}-2$ & V & $\mathrm{x}$ & & $3 / 6,6$ \\
\hline $33 \mathrm{R}-3$ & V & & & $3 / 6$ \\
\hline $34 \mathrm{R}-1$ & V & & & $3 / 6$ \\
\hline $34 \mathrm{R}-2$ & V & $\mathrm{X}$ & & $3 / 6$ \\
\hline $34 \mathrm{R}-5$ & V & & & $3 / 6$ \\
\hline $35 \mathrm{R}-1$ & V & $\mathrm{x}$ & & $2 / 6$ \\
\hline $35 R-2$ & V & $\mathrm{x}$ & & $3 / 6$ \\
\hline $35 R-5$ & V & $\mathrm{x}$ & & $3 / 6$ \\
\hline $36 \mathrm{R}-2$ & V & & & $2 / 6,3 / 6$ \\
\hline $36 \mathrm{R}-3$ & V & $\mathrm{x}$ & & $3 / 6$ \\
\hline $37 \mathrm{R}-1$ & V & $\mathrm{x}$ & & $3 / 6$ \\
\hline $37 \mathrm{R}-2$ & V & $\mathrm{x}$ & & $3 / 6$ \\
\hline $37 R-3$ & $\mathrm{v}$ & $\mathrm{x}$ & & $3 / 6$ \\
\hline $37 R-4$ & V & $\mathrm{X}$ & & $4 / 6$ \\
\hline $37 R-5$ & V & $\mathrm{X}$ & & $2 / 6$ \\
\hline $37 \mathrm{R}-6$ & V & & & $2 / 6$ \\
\hline $38 \mathrm{R}-1$ & V & $\mathrm{X}$ & & $3 / 6,6,4 / 6$ \\
\hline $38 \mathrm{R}-2$ & V & $\mathrm{x}$ & & $4 / 6$ \\
\hline $38 \mathrm{R}-3$ & V & & & $3 / 6$ \\
\hline $38 \mathrm{R}-4$ & v & & & $6,3 / 6$ \\
\hline $38 R-5$ & V & $\mathrm{x}$ & & $6,3 / 6$ \\
\hline $38 \mathrm{R}-6$ & V & $\mathrm{x}$ & & $3 / 6$ \\
\hline $39 \mathrm{R}-1$ & v & $\mathrm{x}$ & & $3 / 6$ \\
\hline
\end{tabular}

a Barron, Larsen, et al. (1989).

above and below are thin (centimeter width) bands showing ii2 and ii3 that in turn are adjacent to bioturbated intervals (ii3/6). Detailed studies of this boundary section can be found in chapters in this volume by Thierstein et al., Schmidt et al., and Barrera and Huber.

\section{Site 737}

The sediments recovered from Site 737 (on the northern tip of the Kerguelen-Heard Plateau; Fig. 1) range from Eocene to Quaternary in age. Trace fossils and ichnofabric were examined in calcareous claystone (Cores 119-737B- 12R through 119-737B41R), calcareous sandy siltstone (Cores 119-737B-10R and 119737B-11R), and diatom ooze (Core 119-737B-8R) corresponding to Units V, IV, and III of Barron, Larsen, et al. (1989), respectively. These strata are late middle Eocene to late Oligocene in age.

Chondrites and Planolites occur throughout the cores. Zoophycos is common in upper Eocene through lower Oligocene chalks but rare in younger strata. Within these strata, however, Zoophycos is not recorded from the sandy siltstone facies. Thalassinoides is preserved in all three facies and is particularly common in the sandy siltstone facies (Table 1).

Ichnofabric indices of 6 (including ii $2 / 6$, ii3/6, and ii $4 / 6$ ) were recorded throughout the Hole $737 \mathrm{~B}$ cores. Primary lami- nations occur, and some are crosscut by Chondrites to produce ichnofabric indices of 2,3 , and 4 .

Chondrites commonly is concentrated in, but not restricted to, burrow fills. Skolithos and other vertical to oblique burrows occur uncommonly throughout with a maximum recorded depth of bioturbation of $10 \mathrm{~cm}$ (Pl. 1, Fig. 6).

\section{DISCUSSION}

Trace fossils can be used to interpret a variety of paleoenvironmental variables. In particular, since publication of Seilacher's (1967) paleobathymetric model, trace fossils have been used to interpret water depth. Throughout the Paleozoic Zoophycos occurred in depositional settings that include shallow-water environments. However, since the Late Cretaceous, Zoophycos has been restricted to outer shelf, slope, and bathyal settings (Bottjer et al., 1988). Thalassinoides is uncommon in deep-sea sediments whereas Planolites and Chondrites are not depth specific (Ekdale and Bromley, 1984a). Ekdale and Bromley (1984a) discussed the distribution of trace fossils in chalk facies and recognized two associations: (1) Chondrites, Planolites, and Zoophycos, characteristic of deep-sea chalks, and (2) Chondrites, Planolites, and Thalassinoides, characteristic of shelf-sea chalks.

Barron, Larsen, et al. (1989) interpreted the Upper Cretaceous strata to have been deposited in a shelf setting and the Tertiary sediments to be middle to deep bathyal in origin. The trace fossils in cores from Holes $737 \mathrm{~B}$ and $738 \mathrm{C}$ are consistent with these interpretations. In these cores, Zoophycos occurs in all facies but is rare in younger strata and was not recorded from the sandy siltstone facies. Thalassinoides is present with uneven distribution in all facies except the chalk. It is relatively common in the sandy siltstone facies and at various intervals within the claystone facies, but is uncommon in the Cretaceous limestone and rare in the ooze (Table 1). The presence of Thalassinoides in Cretaceous limestones is consistent with a shelf setting for the deposition of these strata.

The occurrence of Thalassinoides in sediments interpreted to be bathyal in origin may seem problematic. However, the environmental distribution of Thalassinoides is in a large part controlled by energy rather than by depth per se. Thalassinoides does occur in deeper water sediments associated with relatively high-energy conditions. The calcareous sandy siltstone facies is interpreted to reflect deposition at deep bathyal levels where biogenic accumulations of nannofossil ooze were supplemented by minor sand-silt turbidites, which most likely reflect higher energy conditions. Thalassinoides has also been reported from several turbidite facies elsewhere in the stratigraphic record (e.g., Ekdale et al., 1984; Kern and Warme, 1974; Bottjer, 1981).

Thalassinoides also occurs in the ooze and calcareous claystone, which are deep water in origin. Similarly, Thalassinoides has been reported from intervals in other sequences interpreted to have been deposited in a bathyal setting. For example, in the Monterey Formation of California, Thalassinoides occurs at several intervals with sharp boundaries and coherent clasts in the burrow-fill sediment, suggesting that the sediments were well compacted and possibly partially lithified when the burrow was emplaced (Savrda and Bottjer, 1987). Savrda and Bottjer (1987) suggested that the occurrence of these firmgrounds reflects brief depositional hiatuses or omission surfaces coinciding with the emplacement of Thalassinoides. Currents associated with higher energy conditions possibly effectively removed the mixed layer, leaving behind a firmground. The occurrence of Thalassinoides in the calcareous clay facies and ooze may also reflect a change in depositional conditions.

The distribution of ichnofabric indices is also consistent with shelf and deep-sea sedimentation. Most of the examined sections are thoroughly bioturbated with recorded ichnofabric indices of 6 . In general, thoroughly bioturbated sediments are in- 
dicative of oxygenated conditions, whereas laminated strata may indicate low-oxygen conditions. The rare occurrences of laminated sediments (iil), such as at the Cretaceous/Tertiary boundary, may indicate fluctuating low-oxygen bottom-water conditions.

Studies of discrete trace fossils provide important paleontological and sedimentological information for core studies. In deep-sea sediments, there are fairly predictable and consistent deep-water trace fossil assemblages, and ichnofabric indices tend to be 6 . A departure from these indicates a change in depositional conditions, such as oxygen or energy.

This study shows that it is possible to collect semiquantitative ichnofabric data from ODP cores. This method provides a coherent data base that can be compared with other cores to yield useful insights on the sedimentary history of the ocean basins. Future analysis of ichnofabric and trace fossils from ODP cores that include shallow- and deep-water sediments will further demonstrate ways in which ichnological data can be used to fingerprint facies in core studies.

\section{ACKNOWLEDGMENTS}

We thank Guy Narbonne and Alfred G. Fischer for critical reviews of this manuscript.

\section{REFERENCES}

Barron, J. A., Larsen, B., et al., 1989. Proc. ODP, Init. Repts., 119: College Station, TX (Ocean Drilling Program).

Berger, W. H., and Heath, G. R., 1968. Vertical mixing in pelagic sediments. J. Mar. Res., 26:134-143.

Bjerstedt, T. W., and Erickson, J. M., 1989. Trace fossils and bioturbation in peritidal facies of the Potsdam-Theresa Formations (Cambrian-Ordovician), northwest Adirondacks. Palaios, 4:203-224.

Bottjer, D. J., 1981. Trace fossils from an Upper Cretaceous deep-sea fan, Simi Hills, California. In Link, M. H., Squires, R. L., and Colburn, I. P. (Eds.), Simi Hills Cretaceous Turbidites, Southern California: Pac. Sec., Soc. Econ. Paleontol. Mineral. Guidebook, 5962.

Bottjer, D. J., Droser, M. L., and Jablonski, D., 1988. Palaeoenvironmental trends in the history of trace fossils. Nature, 333:252-255.

Droser, M. L., and Bottjer, D. J., 1986. A semiquantitative field classification of ichnofabric. J. Sediment. Petrol., 56:558-559.

, 1988. Trends in depth and extent of bioturbation in Cambrian carbonate marine environments, western United States. Geology, 16:233-236.
Ekdale, A. A., 1977. Abyssal trace fossils in worldwide Deep Sea Drilling Project cores. In Crimes, T. P., and Harper, J. C. (Eds.), Trace Fossils 2: Geol. J. Spec. Iss., 9:163-182.

, 1978. Trace fossils in Leg $42 \mathrm{~A}$ cores. In Hsü, K. J., Montadert, L., et al., Init. Repts. DSDP, 42: Washington (U.S. Govt. Printing Office), 821-827.

1980. Trace fossils in Deep Sea Drilling Project Leg 58 cores.

In Klein, G. deV., Kobayashi, K., et al., Init. Repts. DSDP, 58: Washington (U.S. Govt. Printing Office), 601-606.

, 1984a. Comparative ichnology of shelf-sea and deep-sea chalk. J. Paleontol., 58:322-332.

Ekdale, A. A., and Bromley, R. G., 1984b. Sedimentology and ichnology of the Cretaceous-Tertiary boundary in Denmark: implications for the causes of the terminal Cretaceous extinction. J. Sediment. Petrol., 54:681-703. 1988. Diagenetic microlamination in chalk. J. Sediment. Petrol., 58:857-861.

Ekdale, A. A., Bromley, R. G., and Pemberton, S. G., 1984. Ichnology: Trace Fossils in Sedimentology and Stratigraphy: Soc. Econ. Paleontol. Mineral. Short Course, 15.

Häntzschel, W., 1975. Trace fossils and problematica (2nd ed.). In Teichert, C. (Ed.), Treatise on Invertebrate Paleontology, Part W, Miscellanea Supplement: Lawrence, Kansas (Univ. Kansas and Geol. Soc. Am.), 1-269.

Hill, P. R., 1987. Chalk solution structures in cores from Deep Sea Drilling Project Leg 94. In Ruddiman, W. F., Kidd, R. B., Thomas, E., et al., Init. Repts. DSDP, 94: Washington (U.S. Govt. Printing Office), 1129-1139.

Kern, J. P., and Warme, J. E., 1974. Trace fossils and bathymetry of the Upper Cretaceous Point Loma Formation, San Diego, California. Geol. Soc. Am. Bull., 85:893-900.

Savrda, C. E., and Bottjer, D. J., 1987. Trace fossils as indicators of bottom-water redox conditions in ancient marine environments. In Bottjer, D. J. (Ed.), New Concepts in the Use of Biogenic Sedimentary Structures for Paleoenvironmental Interpretation: Pac. Sec., Soc. Econ. Paleontol. Mineral. Guidebook, 3-26.

Seilacher, A., 1967. Bathymetry of trace fossils. Mar. Geol., 5:413-428.

Terry, R. D., and Chilingar, G. V., 1955. Summary of "Concerning some additional aids in studying sedimentary formations" by M. S. Shvetsov. J. Sediment. Petrol., 25:229-234.

Date of initial receipt: 21 September 1989

Date of acceptance: 2 February 1990

Ms 119B-206 


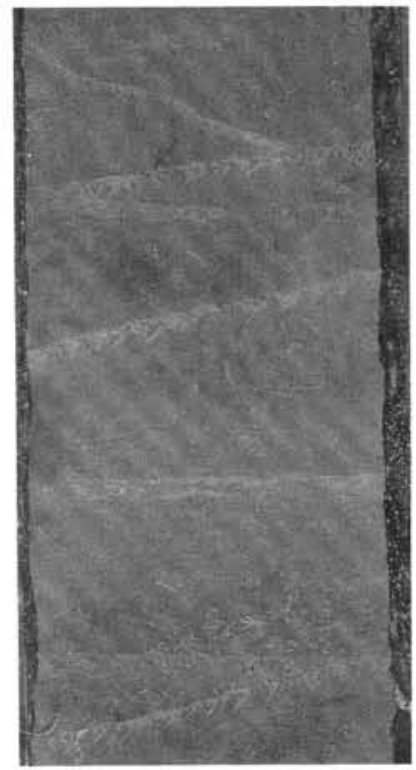

1

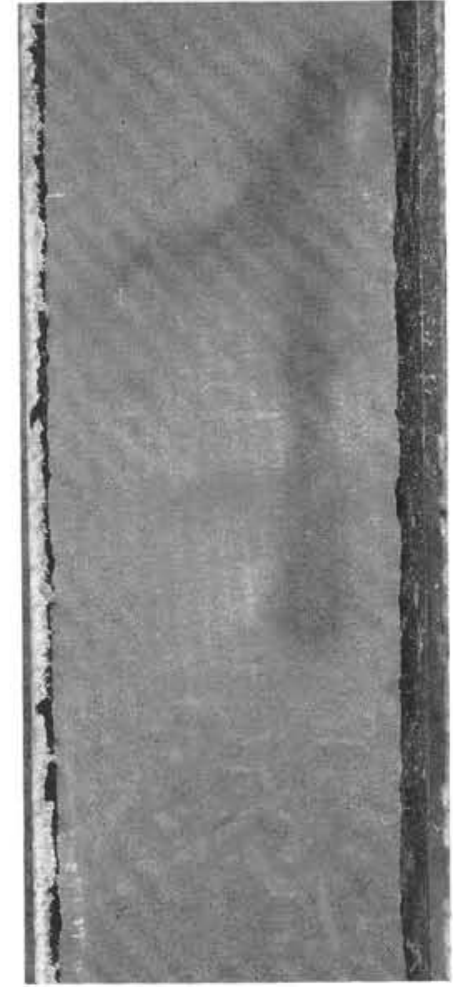

2

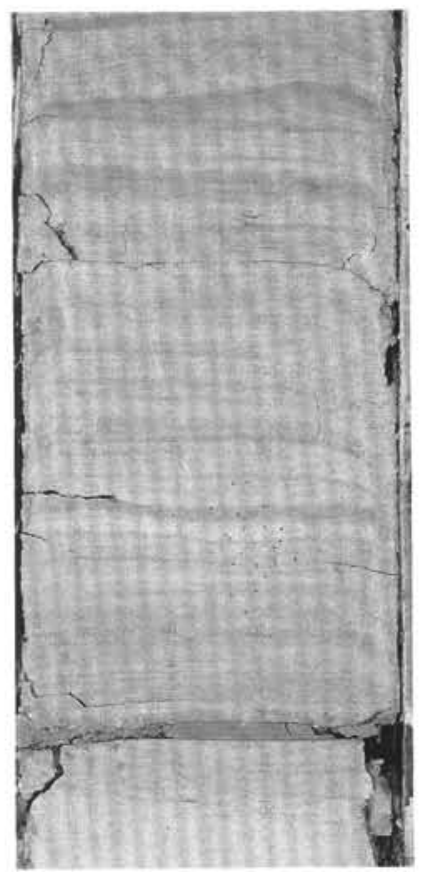

5

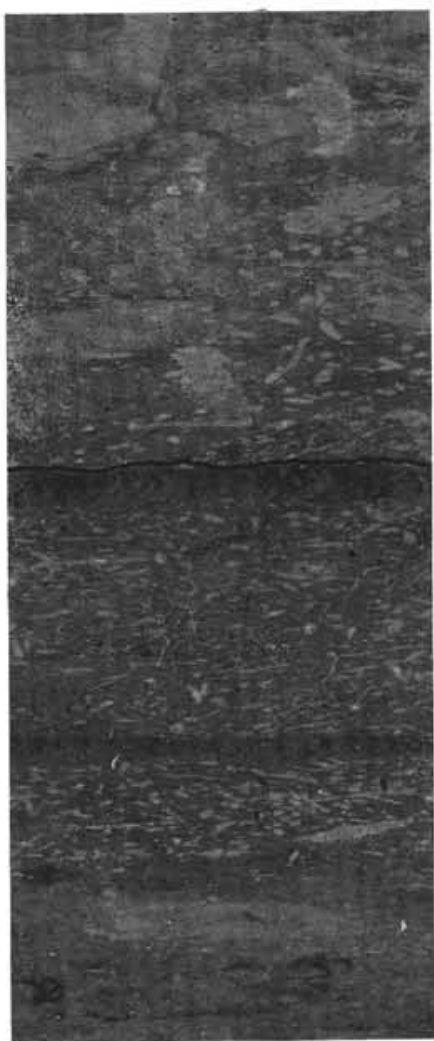

3

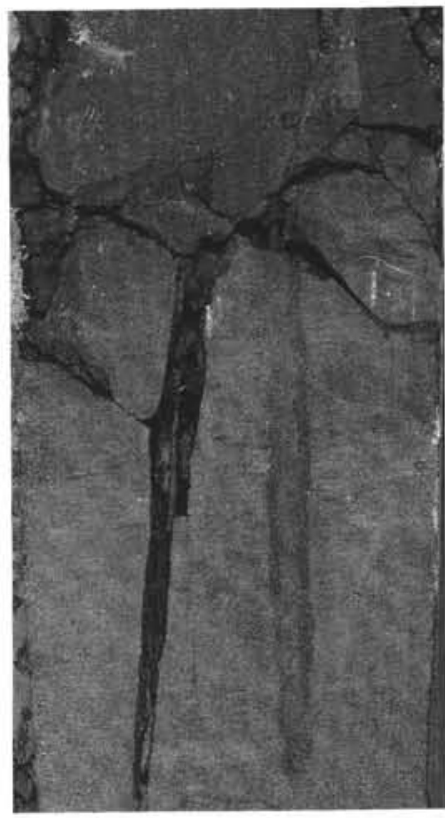

6

Plate 1. 1. Ichnofabric index $3 / 6$ with Zoophycos. Sample 119-738C-20R-5, 55-68 cm. 2. Dense Chondrites, ii4/6. Sample 119-737B-38R-5, 26$36 \mathrm{~cm}$. 3. Branching Thalassinoides. Sample 119-737B-12R-4, 118-135 cm. 4. Diagenetic laminations. Note Chondrites burrows crosscutting laminations. Sample 119-737B-34R-5, 77-91 cm. 5. Laminations (ii1) across the Cretaceous/Tertiary boundary. Sample 119-738C-20R-5, 84-99 cm. 6. Skolithos burrow. Sample 119-737B-28R-1, 48-60 cm. 